\title{
Suitable Oil-Change Intervals for Diesel Railcar Engines
}

\author{
Kazuo NAKAMURA \\ Senior Researcher,
}

Yasutomo SONE

Senior Researcher, Lubricating Materials, Materials Technology Div., RTRI

\author{
Tetsuya HOSOYA \\ Assistant Senior Researcher, \\ Sumiko HIBINO \\ Assistant Senior Researcher,
}

\author{
Masaharu SUZUKI \\ Senior Manager, Railroad \& Aerospace Bearing Technology Dept. \\ Bearing Technology Center, NSK Ltd
}

\begin{abstract}
In order to ascertain a suitable oil-change interval for the higher grade diesel engine oils introduced on diesel railcars, we investigated their durability through field test and then examined the condition of the engines. Based on the test results, we verified that their introduction has enabled oil-change intervals to be extended from the current 20 $35,000 \mathrm{~km}$ to $45,000 \mathrm{~km}$, while keeping good conditions inside the engine.
\end{abstract}

Keywords: diesel engine oil, diesel railcar, internal combustion engine, inspection

\section{Introduction}

The life of a diesel railcar engine is influenced largely by the degradation rate of the diesel engine oil. In order to bring about effective, trouble-free engine maintenance, therefore, it is important to keep engines in good condition by setting an appropriate oil-change interval. With the extension of diesel railcar inspection periods as an incentive, we set out to ascertain an appropriate interval by investigating the durability of engine oils in field tests and the conditions inside the engine after field test.

For this purpose, we first analyzed and evaluated the degradation of current engine oils using the currently accepted interval. Based on the results of this investigation, we then introduced the upgraded engine oils and evaluated their degradation rates in field tests and resulting engine internal inspection after field test. These field tests were also used to confirm whether the oilchange interval thus obtained could be applied to different types of engines. This paper reports on the studies finding.

\section{Evaluation of diesel railcar engine oil degradation}

\subsection{Engine oil degradation}

The performance of engine oil gradually declines with use as it degrades, consumes additives, and is contaminated with soot caused by inefficient fuel combustion. Then, the oil's kinematic viscosity increases and deposits build up inside the engine. If these phenomena are allowed to continue unchecked, they can cause poor lubrication, filter blockage, increased wear and other problems. The excessive consumption of engine oil additives is liable to cause seizure and significantly increase wear on sliding engine surfaces, thereby corroding the outer surfaces of pistons and other parts. These phenomena will have a harmfull effect on engine life. Therefore, it is important to replace engine oils at an appropriate interval to maintain the engine in good working order.

\subsection{Evaluation items}

To evaluate engine oil degradation, we analyzed six items: the increasing kinematic viscosity rate, total base number, n-Heptane insoluble, iron content, water content, and flash point. Each item is outlined below.

(1) Increasing rate of kinematic viscosity: This compares the rate of increase in kinematic viscosity between the old and new oils. The value was increased mainly by the oil oxidation degradation and mixed fuel residue (soot). On the other hand, the principal causes of a decrease were oil shearing and fuel dilution. The kinematic viscosity of an oil sample at $100{ }^{\circ} \mathrm{C}$ was measured in accordance with the procedure in JIS K2283.

(2) Total base number: This is the equivalent amount of potassium hydroxide, equivalent to the required amount of hydrochloric acid, needed to neutralize the basic component contained in $1 \mathrm{~g}$ of the oil. The value shows the oil's detergency/dispersancy (of soot and other by-products) and acid neutralization. The total base number of an oil sample was measured in accordance with JIS K2501 using an automatic potentiometric titration analyzer.

(3) n-Heptane insoluble: This is the amount of degradation by-products in oil, wear particles, soot and other matter produced. The n-Heptane insoluble of an oil sample was measured following the procedure in ASTM D893. The amount of soot cannot be separated completely as an n-Heptane insoluble, because it is finely dispersed by detergent dispersants. Therefore, we measured it using procedure B (ASTM D893) by putting an agglomerate reagent into the engine oil to collect it.

(4) Iron content: There is a large amount of iron produced 
in oil. The purpose of this measurement is to ascertain rate of wear caused by iron inside the engine. The method involves the quantitative analysis of an oil sample dropped on filter paper using a X-ray fluorescence spectrometer.

(5) Water content: Water contamination causes poor lubrication, accelerated oil degradation, corrosion inside the engine and other detrimental phenomena. The ratio of water to oil in the samples was measured according to the Karl Fischer method in JIS K2275.

(6) Flash point: This is measured to confirm whether the engine oil is diluted by fuel contamination, because there is the possibility that this could be the cause of poor lubrication. The flash point of an oil sample was measured using the Cleveland open cup method in JIS K2265.

\subsection{Assessment of engine oil degradation by control target value}

Railroad vehicle diesel engine oil has control target values ${ }^{1)}$ that are indices of the allowable limits for the six evaluation items listed above and act as the standard used to judge whether an oil change is necessary (Table 1 ). When the analysis values of the six items are all within control target parameters, it is assumed that the engine oil has not yet exceeded the degradation limit. We used these control target values to assess the engine oil degradation.

Table 1 Control target values of diesel railroad vehicle engine oils

\begin{tabular}{|l|c|}
\hline Oil property & Control target values \\
\hline Increasing rate of kinematic viscosity & $-30 \% \sim+50 \%$ \\
\hline Total base number & $\geqq 1 \mathrm{mgKOH} / \mathrm{g}$ \\
\hline n-Heptane insoluble (procedure B) & $\leqq 5 \mathrm{mass} \%$ \\
\hline Iron content & $\leqq 0.2 \mathrm{mass} \%$ \\
\hline Water content & $\leqq 0.2 \mathrm{mass} \%$ \\
\hline Flash point & $\geqq 170^{\circ} \mathrm{C}$ \\
\hline
\end{tabular}

\section{Engine oil degradation analysis (current oil types)}

\subsection{Sampling and analysis}

We analyzed the degradation of current types of engine oil that had been used for the current oil-change interval to investigate both the degree of degradation and the factors that influence it. Table 2 outlines the investigation.

For this purpose, we used engines of different types. Types B and C were both used under the same track conditions, but those in the case of type A were different (on gradient and flat sections).
Table 2 Outline of investigation

\begin{tabular}{|c|c|c|}
\hline $\begin{array}{l}\text { ype of engine } \\
\text { putput, oil quantity) }\end{array}$ & $\begin{array}{c}\text { Track } \\
\text { condition }\end{array}$ & $\begin{array}{c}\text { Engine oil (API service classification) } \\
\text { Current oil-change interval } \\
\text { (Distance traveled) }\end{array}$ \\
\hline $\begin{array}{l}\text { A Engine } \\
309 \mathrm{~kW}, 42 \mathrm{~L})\end{array}$ & $\begin{array}{l}\text { Gradient } \\
\text { section }\end{array}$ & $\begin{array}{l}\text { Current oil } 1(\mathrm{CE}) \\
\text { Regular inspection * } \\
\text { (approx. } 20,000 \mathrm{~km})\end{array}$ \\
\hline $\begin{array}{l}\text { A Engine } \\
309 \mathrm{~kW}, 42 \mathrm{~L})\end{array}$ & $\begin{array}{c}\text { Flat } \\
\text { section }\end{array}$ & $\begin{array}{c}\text { Current oil } 2(\mathrm{CD}) \\
\text { Regular inspection * } \\
\text { (approx. } 20,000 \mathrm{~km} \text { to } 35,000 \mathrm{~km} \text { ) }\end{array}$ \\
\hline $\begin{array}{c}\text { B Engine } \\
184 \mathrm{~kW}, 42 \mathrm{~L}) \\
\text { C Engine } \\
184 \mathrm{~kW}, 58 \mathrm{~L})\end{array}$ & $\begin{array}{l}\text { Gradient } \\
\text { section }\end{array}$ & $\begin{array}{c}\text { Current oil } 3(\mathrm{CD}) \\
\text { Regular inspection * } \\
\text { (approx. } 20,000 \mathrm{~km} \text { to } 25,000 \mathrm{~km})\end{array}$ \\
\hline
\end{tabular}

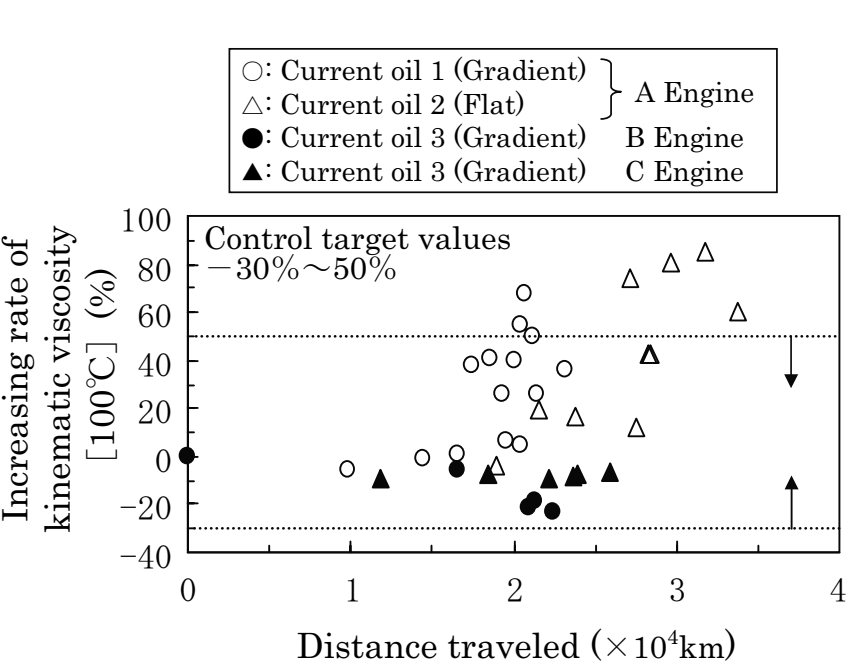

Fig. 1 Degradation analysis results for used current engine oil

(Typical example : Increasing rate of kinematic viscosity)

\subsection{Results of degradation analysis}

The degradation analysis results using current engine oils were evaluated in terms of the six parameters.

Figure 1 shows the results of kinematic viscosity analyses. The following are the results obtained from the degradation analyses of a currently used engine oil.

The increasing rate of kinematic viscosity of used engine oils, which is one of the important evaluation parameters when assessing oil degradation, started to exceed the control target value significantly after the railcar had covered more than $20,000 \mathrm{~km}$ (Fig. 1). There were also some cases where the used engine oil's total base number, another important parameter, began to reach the control target value after the railcar had covered the same distance. Therefore, it became clear that current engine oils lack sufficient anti-degradability and soot dispersibility. It was reconfirmed that railcar oil degradation tends to accelerate when operating on gradient sections. 


\section{Introduction of upgraded engine oils and suitable oil-change intervals}

\subsection{Introduction of upgraded engine oils}

Analysis of current engine oil degradation indicated that the engine oil performance is not sufficient under current operating conditions. On the other hand, extending the time between oil changes would save maintenance work manpower.

To satisfy this requirement, it is necessary for the six engine oil degradation indices to remain within the control target values after the engine oil has been used for longer than the current oil-change interval, with the soot mixed in the engine oil dispersed to keep the engine clean.

Therefore, based on these results, it was decided to introduce two types of upgraded engine oils with API service classifications higher than those of current engine oils. These upgraded engine oils possess superior antidegradability, soot-dispersibility, etc. Table 3 shows the laboratory test results and compares the characteristics of the upgraded and current engine oils.

\subsection{Setting of suitable oil-change interval}

\subsubsection{Field test method}

A field test was performed to assess degradation and to set a suitable oil-change interval for the upgraded engine oils. The field test method used was to extend the oil-change interval gradually by analyzing the degree of degradation, with the degradation of oil samples from diesel railcars evaluated in the same six-point manner as the current engine oil analysis. The suitable oil-change interval is the period during which the engine oil maintains good performance, or the longest operating distance in which degradation does not exceed the control target value.

Table 4 shows an outline of the field test, which was carried out on a gradient section that was more demanding than the flat sections in terms of engine oil degradation. The engine that was used in the field test was a standard A engine with a rated output of $309 \mathrm{~kW}$. We used newly manufactured engines so that we were testing engine oils from the same starting point before comparing current with upgraded engine oils.

\subsubsection{Field test results and discussion}

Figure 2 shows typical results from the field test and the relationship between the analysis values of four typical parameters and the distances covered by the railcars.

In the cases of the two types of upgraded engine oil, both the increasing rate of kinematic viscosity and nHeptane insolubles tended to increase as the distances increased. The total base numbers tended to decrease with distance.

Table 3 Laboratory test results and characteristics of engine oils

\begin{tabular}{|c|c|c|c|c|c|}
\hline Item $\quad$ Engine oil & $\begin{array}{l}\text { Upgraded } \\
\text { oil } 1\end{array}$ & $\begin{array}{l}\text { Upgraded } \\
\quad \text { oil } 2\end{array}$ & $\begin{array}{l}\text { Current } \\
\text { oil } 1\end{array}$ & $\begin{array}{c}\text { Current } \\
\text { oil } 2\end{array}$ & $\begin{array}{l}\text { Current } \\
\text { oil } 3\end{array}$ \\
\hline $\begin{array}{l}\text { API service } \\
\text { classification }\end{array}$ & $\mathrm{CF}-4$ & $\mathrm{CF}$ & $\mathrm{CE}$ & $\mathrm{CD}$ & $\mathrm{CD}$ \\
\hline Base oil & Mineral oil & $\begin{array}{l}\text { Mineral oil } \\
\text { and } \\
\text { synthetic oil }\end{array}$ & Mineral oil & Mineral oil & Mineral oil \\
\hline $\begin{array}{l}\text { Kinematic viscosity } \\
{\left[100^{\circ} \mathrm{C}\right]\left(\mathrm{mm}^{2} / \mathrm{s}\right)}\end{array}$ & 14.26 & 13.18 & 14.01 & 12.74 & 13.04 \\
\hline $\begin{array}{l}\text { Total base number } \\
(\mathrm{mgKOH} / \mathrm{g})\end{array}$ & 11.92 & 13.72 & 11.18 & 10.42 & 12.20 \\
\hline $\begin{array}{l}\text { Wear test }{ }^{* 1} \\
\text { Wear track }(\mathrm{mm})\end{array}$ & 0.33 & 0.30 & 0.46 & 0.45 & 0.47 \\
\hline $\begin{array}{l}\text { Thermal degradation test }{ }^{* 2} \\
\text { n-Heptane insoluble } \\
(\operatorname{mass} \%)\end{array}$ & $\leqq 0.001$ & $\leqq 0.001$ & 0.01 & 0.01 & 0.01 \\
\hline $\begin{array}{l}\text { Total base number } \\
(\mathrm{mgKOH} / \mathrm{g})\end{array}$ & 4.23 & 3.56 & 1.58 & 1.59 & 2.38 \\
\hline
\end{tabular}

*1 Load: 392N, Revs: 1,200 $\mathrm{min}^{-1}$, Test time: $30 \mathrm{~min}$

*2 Test oil temperature: $165.5^{\circ} \mathrm{C}$, Test time: $24 \mathrm{~h}$

Table 4 Engine oil field test parameters

\begin{tabular}{|c|c|c|c|c|}
\hline Engine type & \multicolumn{4}{|c|}{ A Engine, Rated output: $309 \mathrm{~kW}$, Oil quantity: $42 \mathrm{~L}$} \\
\hline Track condition & \multicolumn{4}{|c|}{ Gradient section } \\
\hline Engine oil & Upgraded oil 1 & Upgraded oil 2 & \multicolumn{2}{|c|}{ Current oil 1} \\
\hline Number of engines & 2 & 2 & 1 & 1 \\
\hline $\begin{array}{l}\text { Oil-change interval } \\
\text { (Distance traveled) }\end{array}$ & \multicolumn{3}{|c|}{ Approx. $40,000 \mathrm{~km}$ to $50,000 \mathrm{~km}$} & $\begin{array}{l}\text { Approx. } \\
20,000 \mathrm{~km} \\
\text { to } 35,000 \mathrm{~km}\end{array}$ \\
\hline Oil filter & \multicolumn{4}{|c|}{ Changed at every regular inspection } \\
\hline
\end{tabular}




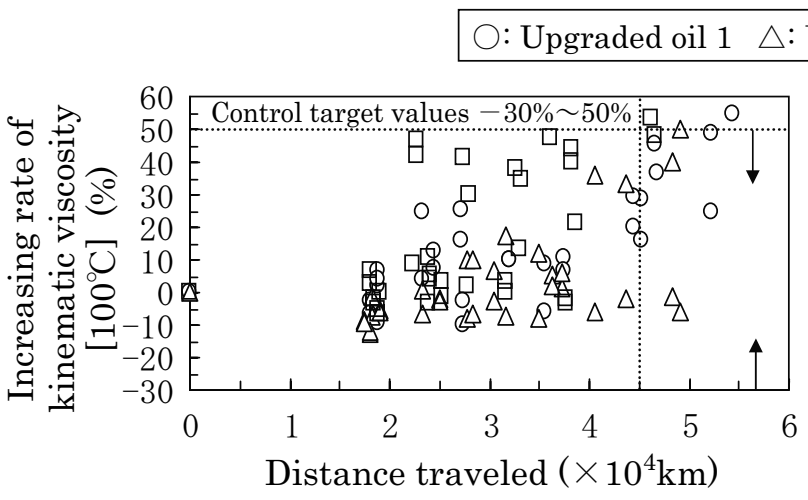

(a) Increasing rate of kinematic viscosity

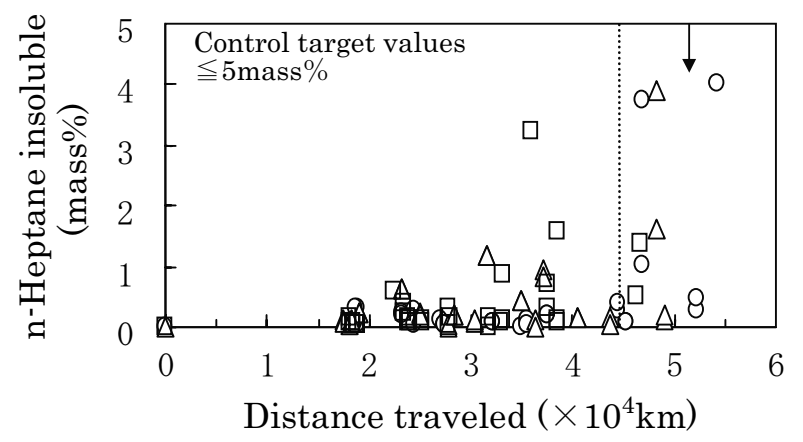

(c) n-Heptane insoluble

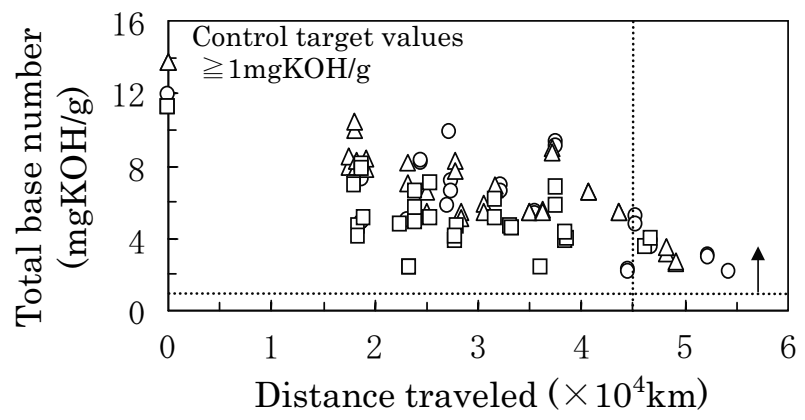

(b) Total base number

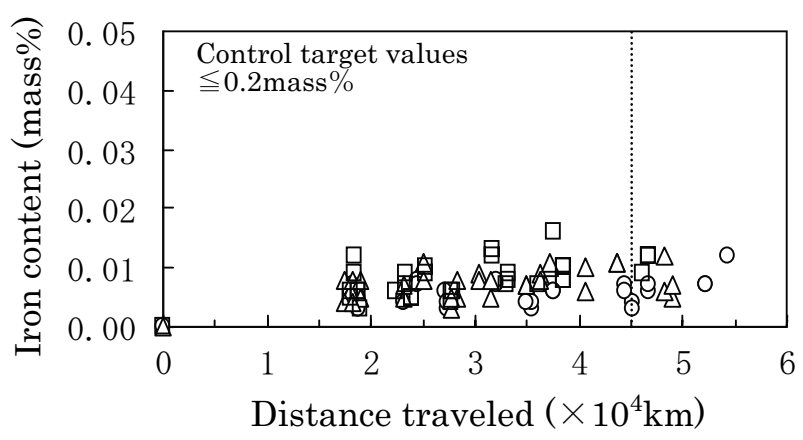

(d) Iron content

Fig. 2 Field test results

The degradation of upgraded oil is approximately related to the distance covered. The increasing rate of kinematic viscosity of the upgraded engine oils used began to exceed the control target value at a distance of 50,000 $\mathrm{km}$ or over, the total base number of used engine oils approaching the control target value at around the same distance. From these results, it is predicted that, when upgraded diesel engine oils are used over this distance, the degradation of engine oil continues and that the oil lubricating performance will drop due to soot contamination, consumption of detergent dispersant and other reasons. The iron content was sufficiently lower than the control target value. It was also shown that the amount of wear on the engine was negligible. Regarding other items of analysis, the water content was below 0.005 mass\% in all test cases and the flash point $216-232{ }^{\circ} \mathrm{C}$, both thus being within their control target values. On the other hand, both the rate of kinematic viscosity and the total base number of the currently used engine oil had already begun to reach their control target values even at $20,000 \mathrm{~km}$.

From the above results, the suitable oil-change interval of the two types of upgraded engine oil is $45,000 \mathrm{~km}$ in terms of distance and degradation limit.

\subsection{Engine internal inspection}

We needed to clarify that the suitable oil-change interval of these upgraded engine oils was $45,000 \mathrm{~km}$ in terms of distance not only from the viewpoint of degradation limit but also from that of engine maintenance. To confirm this fact, the engines were disassembled after the field tests and inspected to evaluate whether their parts were clean and damage-free, and that the wear rate was low.

\subsubsection{Cleanliness inside engine}

The cleanliness of the engine parts, especially pistons, was evaluated according to the "Diesel Piston Rating Method for Rail Cars and Locomotives" and the coefficient in the standard for cleanliness evaluation from "JPI Diesel Piston Rating Method" 2) applied. Figure 3 shows the assessed parts of a piston and Table 5 the piston cleanliness evaluation standard. For each rating, the best condition is expressed as point 0 , and the worst as point 10 .

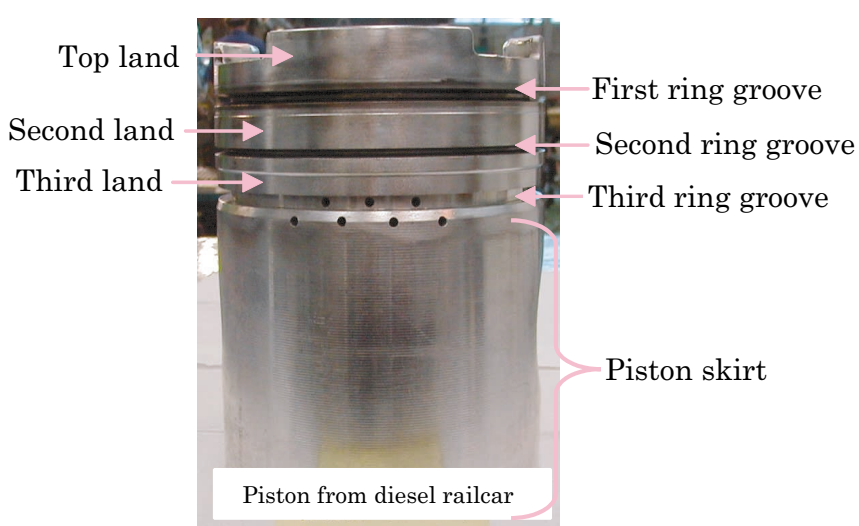

Fig. 3 Evaluated piston parts 
Table 5 Piston cleanliness evaluation standard

\begin{tabular}{|c|c|c|c|c|}
\hline \multirow{2}{*}{$\begin{array}{l}\text { Evaluated } \\
\text { item }\end{array}$} & \multirow[b]{2}{*}{ Evaluated part } & \multicolumn{2}{|c|}{ Evaluated standard } & \multirow[b]{2}{*}{ Rating } \\
\hline & & Color & $\begin{array}{l}\text { Coefficient } \\
\text { of color }\end{array}$ & \\
\hline \multirow{3}{*}{$\begin{array}{l}\text { Deposit } \\
\text { location }\end{array}$} & $\begin{array}{l}\text { First ring groove } \\
\sim \text { Third ring groove }\end{array}$ & $\begin{array}{c}\text { Clean } \\
\text { Very light amber lacquer }\end{array}$ & $\begin{array}{l}0 \\
0.01\end{array}$ & \multirow{3}{*}{$\begin{array}{l}\text { Rating of } \\
\text { deposit }^{* 1}\end{array}$} \\
\hline & $\begin{array}{l}\text { Top land } \\
\text { Second land } \\
\text { Third land }\end{array}$ & $\begin{array}{l}\text { Light amber lacquer } \\
\text { Amber lacquer } \\
\text { Dark brown lacquer }\end{array}$ & $\begin{array}{l}0.025 \\
0.050 \\
0.075\end{array}$ & \\
\hline & Piston skirt & Black lacquer & 0.10 & \\
\hline \multirow{2}{*}{$\begin{array}{l}\text { Carbon } \\
\text { cutting }^{* 2}\end{array}$} & \multirow[b]{2}{*}{ Top land } & Condition & $\begin{array}{l}\text { Coefficient of } \\
\text { cutting }\end{array}$ & \multirow{2}{*}{$\begin{array}{l}\text { Rating of carbon } \\
\text { cutting }^{* 4}\end{array}$} \\
\hline & & $\begin{array}{l}\text { Nothing } \\
\text { Light*3 }^{* 3} \\
\text { Heavy }^{* 3}\end{array}$ & $\begin{array}{l}0 \\
0.5 \\
1.0\end{array}$ & \\
\hline \multirow[b]{2}{*}{$\begin{array}{l}\text { Piston } \\
\text { Ring }\end{array}$} & \multirow[b]{2}{*}{$\begin{array}{l}\text { First piston ring } \\
\sim \text { Third piston ring }\end{array}$} & \multicolumn{2}{|c|}{ Condition } & \multirow[b]{2}{*}{$\begin{array}{l}0 \\
0.5 \\
3 \\
8 \\
10\end{array}$} \\
\hline & & \multicolumn{2}{|c|}{$\begin{array}{c}\text { Free }^{* 5} \\
\text { Sluggish }^{* 6} \\
\text { Pinched }^{* 7} \\
\text { Stuck }^{* 8} \\
\text { Damaged }\end{array}$} & \\
\hline
\end{tabular}

*1 Rating of deposit $=$ Area of deposit $\% \times$ coefficient of color

*2 Damage produced on the metal surface top land by carbon (soot deposit)

*3 Light when the depth of damage is below $0.2 \mathrm{~mm}$, and heavy when the depth of damage is above $0.2 \mathrm{~mm}$

$* 4$ Carbon cutting rating $=($ damaged area $\% \times$ coefficient of cutting $) / 10$

*5 Piston ring moves under its own weight when the piston is turned sideways

*6 Piston ring moves when pushed lightly by a finger, but not under its own weight

*7 Piston ring does not move when pushed lightly by a finger. However, the piston ring periphery is lustrous, and seems to fulfill its function when the engine is turning

*8 Piston ring does not move when pushed by a finger with the periphery of piston ring covered with carbon and lacquer, and it seems not to fulfill its function when the engine is turning

Table 6 Evaluated piston cleanliness results (A Engine)

Distance covered by each engine: Approx. 240,000 km

\begin{tabular}{|c|c|c|c|c|c|c|}
\hline \multicolumn{2}{|l|}{ Engine oil } & \multicolumn{2}{|c|}{ Upgraded oil 1} & \multicolumn{2}{|c|}{ Upgraded oil 2} & $\begin{array}{c}\text { Current } \\
\text { oil } 1\end{array}$ \\
\hline \multicolumn{2}{|l|}{ Number of engines } & \multicolumn{2}{|c|}{2} & \multicolumn{2}{|c|}{2} & 1 \\
\hline \multicolumn{2}{|c|}{ Evaluated item and parts $\quad \begin{array}{r}\text { Oil-change interval } \\
(\mathrm{km})\end{array}$} & \multicolumn{4}{|c|}{ Approx. 45,000 to 50,000} & $\begin{array}{l}\text { Approx. } \\
20,000 \\
\text { to } 35,000\end{array}$ \\
\hline Deposit at ring grooves & $\begin{array}{l}\text { The sum of rating* } \\
\text { from the first to the } \\
\text { third }\end{array}$ & 20.0 & 20.0 & 19.0 & 20.0 & 20.1 \\
\hline Deposit at lands & $\begin{array}{l}\text { The sum of rating* } \\
\text { from the top to the } \\
\text { third }\end{array}$ & 21.1 & 21.1 & 19.1 & 19.8 & 22.0 \\
\hline Skirts & Rating* of skirts & 0.0 & 0.0 & 0.1 & 0.1 & 0.1 \\
\hline Carbon cutting & Rating* of top lands & 0.2 & 1.0 & 0.8 & 0.2 & 3.2 \\
\hline Locked piston ring & $\begin{array}{l}\text { The sum of rating* } \\
\text { from the first to the } \\
\text { third }\end{array}$ & 0.0 & 0.0 & 0.0 & 0.0 & 0.0 \\
\hline \multicolumn{2}{|l|}{ Total } & 41.3 & 42.1 & 39.0 & 40.1 & \multirow{2}{*}{$\begin{array}{l}\text { Total } \\
45.4\end{array}$} \\
\hline \multicolumn{2}{|l|}{ Average of two engines } & \multicolumn{2}{|c|}{41.7} & \multicolumn{2}{|c|}{39.6} & \\
\hline
\end{tabular}

* The rating at each part is the average of piston No.1 to piston No.6 of each engine 


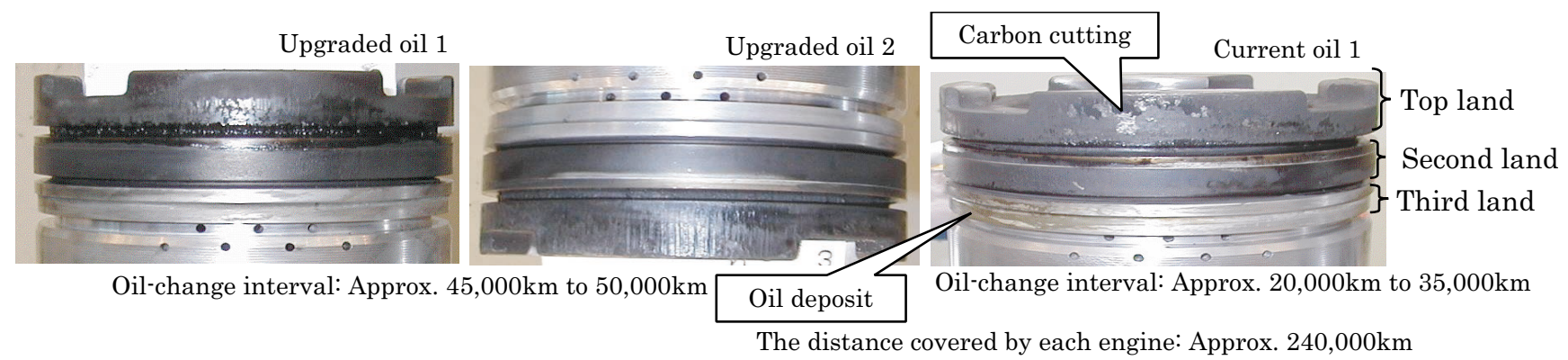

Fig. 4 The cleanliness of piston head (typical examples)

Table 6 shows the evaluated piston cleanliness results for the A Engine, and Fig. 4 shows typical examples of piston head cleanliness. From the evaluation, the inside of engines using the upgraded oils whose oil-change interval was a distance of approximately $45-50,000 \mathrm{~km}$ was cleaner and had fewer deposits on the piston than those using current engine oils with an interval of around $20-35,000 \mathrm{~km}$.
Table 7 Wear depth of the part of engine (A Engine)

Allowable value: $\leqq 0.20 \mathrm{~mm}$

\begin{tabular}{|l|c|c|c|c|c|}
\hline Engine oil & \multicolumn{2}{|c|}{$\begin{array}{c}\text { Upgraded } \\
\text { oil 1 }\end{array}$} & \multicolumn{2}{c|}{$\begin{array}{c}\text { Upgraded } \\
\text { oil 2 }\end{array}$} & $\begin{array}{c}\text { Current } \\
\text { oil 1 }\end{array}$ \\
\hline $\begin{array}{l}\text { Oil-change interval } \\
\text { Distance covered (km) }\end{array}$ & \multicolumn{3}{|c|}{ Approx. 45,000 to 50,000 } & $\begin{array}{c}\text { Approx. } \\
20,000 \\
\text { to } 35,000\end{array}$ \\
\hline $\begin{array}{l}\text { Wear depth of the part of } \\
\text { valve cross head pad on } \\
\text { intake valve side* }(\mathrm{mm})\end{array}$ & 0.025 & 0.025 & 0.025 & 0.015 & 0.025 \\
\hline
\end{tabular}

* Each value is the average at six places (cylinder No.1 to cylinder No.6)

\subsubsection{Measurement of dimensions and engine part wear}

After the field test, we measured dimensions and wear depth of the main engine parts to investigate engine wear. The dimensions of the main parts were the bore of the cylinder bush, the diameter of the crankshaft, and others. The part measured for wear depth was the valve cross head pad on the intake valve side where the most wear appears among the parts of the dynamic valve gear.

As a result, with regard to the engine using the upgraded oil that needs to be changed after $45-50,000 \mathrm{~km}$ and the engine using the current oil $(20-35,000 \mathrm{~km})$, each main part measurement was within permissible values, as was the wear depth of the valve cross head pad on the intake valve side (Table 7 ). These matched the analysis results of the iron content gained in field tests that showed that the iron content was lower than the control target value.

\subsubsection{Results of engine inspection}

Though the oil-change interval on the upgraded engine oils was more demanding than that of current engine oils, the main engine parts were in a better state in terms of deposits and cleanliness, and the amount of wear extremely light. From these results, the inside of the engines using the upgraded oil with the $45-50,000 \mathrm{~km}$ oil change were kept in a good condition. Therefore, the oilchange interval of $45,000 \mathrm{~km}$ in terms of running distance was appropriate from the viewpoint of engine maintenance.

\subsection{Field test with another type of diesel engine}

In the results covering the degradation analysis of currently used engine oils (Fig. 1), the increasing rate of kinematic viscosity differed depending on the type of diesel engines. The increasing rate of kinematic viscosity of oils used in the A Engine had a tendency to increase with the distance covered by the railcar, as mentioned above. On the other hand, the increasing rate of kinematic viscosity of oils used in the B and C Engines had a tendency to decrease with distance. Therefore, we performed more field tests for upgraded engine oils in order to clarify that the oil-change interval of $45,000 \mathrm{~km}$ is applicable to the $B$ engine (the oil degradation of $B$ engine is more intense than that of $\mathrm{C}$ engine), when oil filters are changed at every regular inspection.

The results obtained from the field tests for the B engine matched those obtained from previous field tests. It could be verrified, therefore, that the $45,000 \mathrm{~km}$ oilchange is applicable to different types of diesel engine. Figuer 5 shows a typical example of the increasing rate of kinematic viscosity.

$\bigcirc$ : Upgraded oil $1 \quad \triangle$ : Upgraded oil $2 \quad$ ○: Current oil 3

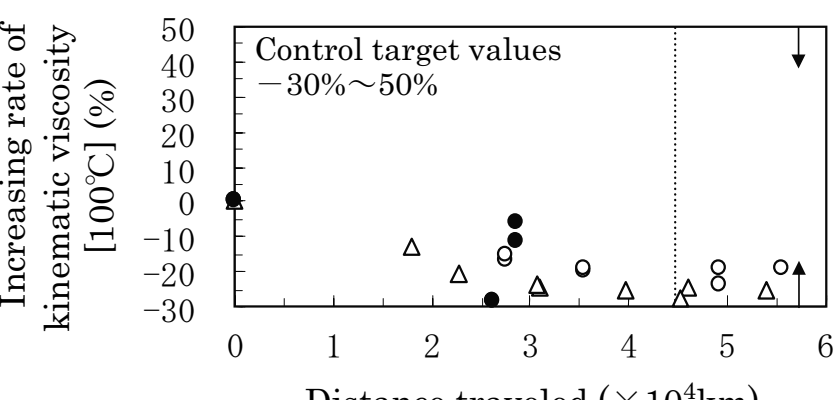

Fig. 5 Increasing rate of kinematic viscosity (B Engine [184kW], gradient)

\section{Conclusions}

The results obtained can be summarized as follows:

(1) It is advisable to introduce upgraded engine oils that possess superior anti-degradability and soot- 
dispersibility, etc., for diesel railcars to extend oil- kept good. change intervals.

(2) It is possible to extend the oil-change intervals of those upgraded engine oils to $45,000 \mathrm{~km}$ in terms of distance covered, with oil filters changed at every regular inspection.

(3) The inside of engines using the upgraded engine oils (oil-change intervals approx. $45,000 \mathrm{~km}$ to $50,000 \mathrm{~km}$ ) was cleaner and had fewer piston deposits than those using the current engine oils (approx. 20,000 km to $35,000 \mathrm{~km}$ ). The wear rate was low in both cases.

(4) The oil-change interval of $45,000 \mathrm{~km}$ for upgraded engine oils is applicable to other types of engine that possess different performance in terms of durability.

From the above results, by introducing upgraded diesel engine oils, it is possible to extend the oil-change interval to $45,000 \mathrm{~km}$ with the condition inside the engine

\section{Acknowledgment}

The authors would like to express their sincere gratitude to the East Japan Railway Company personnel concerned for their kind cooperation in the execution of this research and its associated field tests.

\section{References}

1) Suzuki, M.: "Lubricant for Railroad Vehicles, Tribologist," Vol. 35, No. 2, pp.101-106, 1990.

2) JPI STANDARD.: "JPI Diesel Piston Rating Method," JPI-5S-15-94, The Japan Petroleum Institute, 1994. 